\title{
Effect of Landfill Leachate on Groundwater Contamination: A case study of Obio- Akpo Local Government Area, Rivers State, Nigeria
}

\author{
GOLDEN, AH; *INICHINBIA, S \\ Department of Physics, University of Port Harcourt, Port Harcourt, Nigeria \\ *Corresponding Author Email: sonny.inichinbia@yahoo.com,sonny.inichinbia@uniport.edu.ng
}

\begin{abstract}
This research investigates the effect of landfill leachate on the groundwater in "Odum", a community that plays host to a dumpsite along Choba/Alakahia road in Obio/Akpor Local Government Area (L.G.A.) of Rivers State, Nigeria. Five vertical electrical soundings (VES) were conducted using the Schlumberger configuration and also five horizontal profiling were done using the Wenner configuration. The field data were acquired using ABEM tarrameter SAS 300C, and processed using the IP TWO WAY software. The results showed that the area is composed of sandstone, clay, laterite, sandy clay, and sand. Also, from careful analysis and interpretation of the processed data it was observed that contaminated zones have low resistivity (high conductivity). Strikingly, areas of low resistivity such as $11.9 \Omega \mathrm{m}$ and others with high resistivity up to greater than $1818 \Omega \mathrm{m}$ do exist. The results show that groundwater around this landfill contaminated area contains highly conductive leachates like sulphur, methane, ammonia gas at depths $>16 \mathrm{~m}$. This indicates that the study area is not a good aquifer zone.
\end{abstract}

DOI: $\underline{\text { https://dx.doi.org/10.4314/jasem.v24i8.10 }}$

Copyright: Copyright (C) 2020 Golden and Inichinbia. This is an open access article distributed under the Creative Commons Attribution License (CCL), which permits unrestricted use, distribution, and reproduction in any medium, provided the original work is properly cited.

Dates: Received: 30 May 2020; Revised: 03 July 2020; Accepted: 05 August 2020

Keywords: Resistivity, Landfill, Leachate, Groundwater, Dumpsite, Aquifer, Sounding

Several works have been done on different dumpsites in many parts of the world, and also, in Nigeria that show how the quality of groundwater and human health is affected by leachate percolation into underground water bodies. Such works, among others include those of Udom and Esu 2004; Udom et al. 1999; Rosqvist et al. 2003; Ibe and Njoku 1999; Inichinbia and Sule 2018a; Inichinbia and Sule 2018b; Olayinka and Olayiwole 2000; Ehirim et al. 2009a; Ehirim et al. 2009b; Adebibu, 1985; Agbemuko et al. 2017; Ajadike 2007; Ige and Ogunsanwo 2009; Adekunle and Kehinde 2008; Eshimiakhe et al. (2019). The total amount of water in the earth is virtually constant but its distribution over time and space varies to a great extent. Wherever people live, they must have a clean and continuous supply of water as a primary requirement for human existence. The assessment of the quality, supply and renewal of water is quite a well-known problem, but it is becoming critical with the growth of population and rapid industrialization. The rising population of Nigeria of about 180 million requires knowledge of the proper disposal of wastes. This is because wastes are dumped recklessly with little environmental regards in major cities of many states in Nigeria including Rivers State. Increase in population, changes or improvement in wages, massive expansion of the urban areas and the changing lifestyle or better standard of living, as well as improvement in technology in Nigeria has encouraged solid waste generation. Although solid waste is an asset when properly managed, its volume has continued to increase tremendously in recent times. In Nigeria, much has been, and is still being invested on municipal solid waste management in cities. But little progress has been made because of severe financial, technological and institutional constraints within the public and the private sectors. Waste could be defined as any material lacking direct value to the producer and so must be disposed of. Similarly, waste is any material that is thrown away as unwanted material. The term "solid waste" means any garbage, refuse, or sludge from a waste treatment plant, water supply treatment plant, or air pollution control facility and other discarded materials, including solid, liquid, semi-solid, industries, mining etc. Solid waste can however be classified into different types, depending on their source; household waste is generally classified as municipal waste; industrial waste as hazardous waste, and biomedical waste or hospital waste as infectious waste. The trend of indiscriminate or uncontrolled and haphazard construction of groundwater facilities particularly shallow wells and boreholes in the residential areas close to refuse dumpsites is of great health concern, as this may contribute significantly to groundwater pollution. This results to an adverse impact on the aquifer as a result of overdependence and over abstraction with attendant negative effects. The Odum

*Corresponding Author Email: sonny.inichinbia@yahoo.com, sonny.inichinbia@uniport.edu.ng 
dumpsite is not well managed over the years and has contaminated the aquifer with leachate. As a matter of fact people within this settlement have been drilling boreholes from this very contaminated zone as a result of ignorance, thereby endangering their lives. Also the decomposition of municipal solid waste causes serious airborne diseases and releases methane a greenhouse gas contributing to climate change. The objective of this paper is to evaluate the effect of landfill leachate on groundwater contamination within the study area.

\section{MATERIALS AND METHODS}

Study Area: The study area is Obio-Akpo Local Government Area of Rivers State Nigeria (Figure 1).

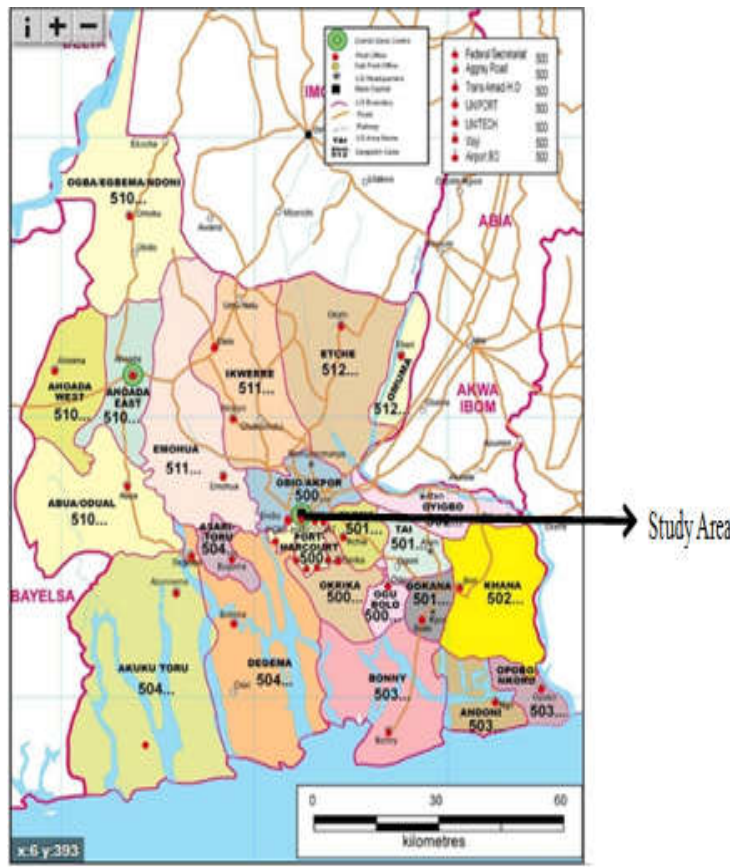

Fig 1. Map of Niger Delta showing Rivers State and the Study Area

Methodology: The geophysical method used was the resistivity method employing both Schlumberger electrode configuration (VES) and the Werner electrode configuration for profiling. Electrical Resistivity Tomography (ERT) are surface geophysical methods in which an electrical current is injected into the ground through electrodes and voltages on the surface are measured revealing the direction and amount of current flow in the subsurface. The data is used to image the subsurface resistivity.

Observed measurements of the current and voltages are converted into apparent resistivity, a weighted average of the resistance of earth materials to current flow. Variations in fluid saturation, fluid resistivity, rock type, porosity, and permeability affect resistivity values and are often revealed with the electrical resistivity methods.

Data Analysis and Interpretation: The data obtained from the field survey were processed using the IP TWO WAY software, analysed and interpreted using modern techniques demonstrated by Inichinbia and Sule 2018a; Inichinbia and Sule 2018b; Olayinka and Olayiwole 2000; Ehirim et al. 2009a; Ehirim et al. 2009b; Adebibu, 1985; Agbemuko et al. 2017; Tamuno and Inichinbia, 2019; Eshimiakhe et al. (2019) and a host of other authors. The results are presented in appropriate sections and table and discussed in the results and discussions section.

\section{RESULTS AND DISCUSSION}

Profile 1 (see Figure 2) was acquired $10 \mathrm{~m}$ away from the landfill. The inverse model resistivity section has resistivity values ranging from less $1.67 \Omega \mathrm{m}$ to greater $541.00 \Omega \mathrm{m}$. There is a zone of anomalously low resistivity in the inverse model section of depth ranging from $1.25 \mathrm{~m}$ to $15.90 \mathrm{~m}$ and at surface points from $25.00 \mathrm{~m}-85.00(>65.00 \mathrm{~m})$ the zone of low resistivity $(>10.20 \Omega \mathrm{m})$ at the upper point of the inverse model section could be associated with highly conductive leachate contaminant plume originating from the decomposition of the various wastes due to the landfill seeping into the aquifer and also indicate contamination of the surrounding soil. Under the low resistivity zones are layers of increasing resistivity (yellow and green) with resistivity values ranging from $25.20 \Omega \mathrm{m}-62.30 \Omega \mathrm{m}$ at depths ranging from $9.26 \mathrm{~m}$ to greater than $16.00 \mathrm{~m}$ and at surface points ranging $17.00 \mathrm{~m}$ to greater than $95.00 \mathrm{~m}(>70.00 \mathrm{~m})$. These layers are interpreted as permeable sandy formation of varying grain sizes, thicknesses and moisture content. Above the zone of increasing resistivity is a zone of anomalously high resistivity greater than $941.00 \Omega \mathrm{m}$ at a depth between $3.75 \mathrm{~m}$ to greater than $15.9 \mathrm{~m}$ which could be interpreted as dissolved landfill gas produced as a result of the decomposition of the landfill waste. The extremely high resistivity portions (red), and $>1256.00 \Omega \mathrm{m}$, are probably hard rocks transported and buried over time as a result of construction works (Inichinbia and Sule, $2018 \mathrm{a} \& \mathrm{~b})$. These materials are found at depths ranging $<2.00 \mathrm{~m}$ to $>9.00 \mathrm{~m}$ and at surface locations $20.00 \mathrm{~m}$ to $35.00 \mathrm{~m}, 45.00 \mathrm{~m}$ to $55.00 \mathrm{~m}, 60.00 \mathrm{~m}$ to $75.00 \mathrm{~m}$ and $80.00 \mathrm{~m}$ to about $95.00 \mathrm{~m}$, across the field. Profile 2 (see Figure 3) was acquired $25.00 \mathrm{~m}$ away from the landfill. The inverse model resistivity section has resistivity values ranging from less than $11.90 \Omega \mathrm{m}$ to greater than $1818.00 \Omega \mathrm{m}$. There is a zone of anomalously low resistivity (deep blue) in the inverse model resistivity section at depths ranging from $1.25 \mathrm{~m}$ to greater than $12.50 \mathrm{~m}$ and at the surface 
points ranging from $15.00 \mathrm{~m}$ to greater than $30.00 \mathrm{~m}$, between $45.00 \mathrm{~m}$ and $50.00 \mathrm{~m}$, and $75.00 \mathrm{~m}$ to greater than $95.00 \mathrm{~m}(>65.00 \mathrm{~m})$. The zone of low resistivity $(50.20 \Omega \mathrm{m})$ at the upper part of the inverse model resistivity section could be associated with highly conductive leachate, since contaminant plume originating from the decomposition of the various wastes dumped on the site has seeped into the aquifer and possibly caused the contamination of the surrounding soil too. The upper zone and layers have decreasing resistivity (green to yellow) with resistivity ranging from $103.00 \Omega \mathrm{m}-170.00 \Omega \mathrm{m}$ at depths ranging from $6.30 \mathrm{~m}$ to a depth greater than $16 \mathrm{~m}$ and at surface points ranging from $15.00 \mathrm{~m}$ to greater than $95.00 \mathrm{~m}(>80.00 \mathrm{~m})$. These layers are permeable sand Formation of varying grain sizes, thicknesses and moisture contents (Tamuno and Inichinbia, 2019; Eshimiakhe et al., 2019). This site is no longer has a good aquifer zone because of the impact of the leachate from the dumpsite.

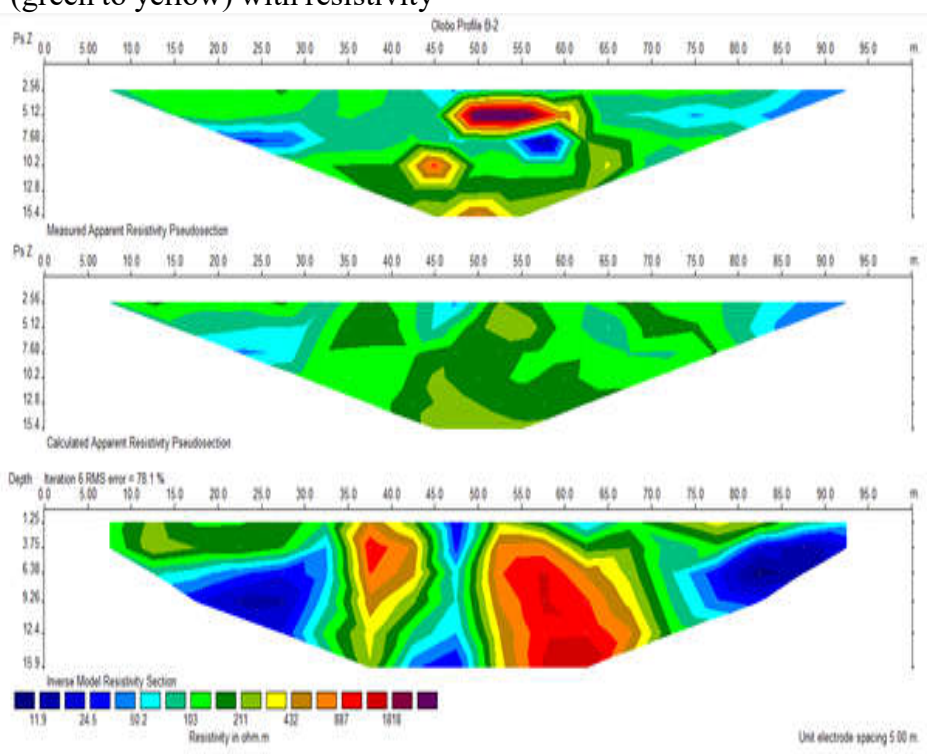

Fig 2. Inverse model resistivity section of profile 1. The model is the result of the simultaneously processed horizontal profiling and vertical profiling data.

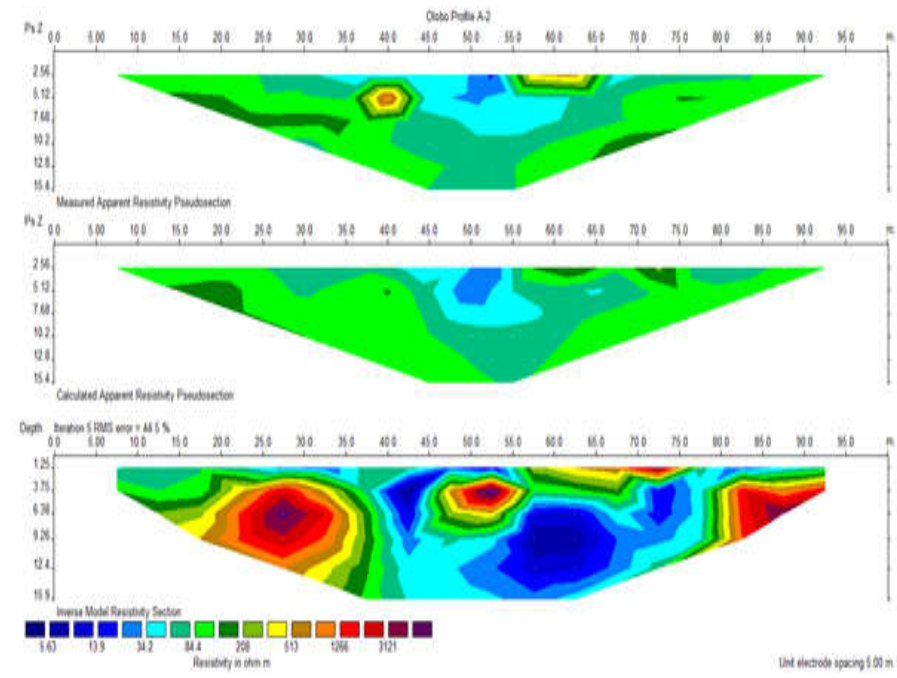

Fig 3. Inverse resistivity model section of profile 2 . The section is the result of the simultaneously processed horizontal profiling and vertical profiling

From the results of the 2D resistivity imaging it is clear that the top soil and groundwater around the landfill site to depth exceeding $16 \mathrm{~m}$ which is within the aquifer in the study area, have been contaminated by the leachate. The results of the $2 \mathrm{D}$ resistivity imaging isolated three zones in each profile mapped around the 
landfill site. These are the zones of anomalously low resistivity which are regarded as highly conductive leachate contaminated zones and contain pathogens that causes health problems. Secondly, a zone of anomalously high resistivity as fill wastes and thirdly, a zone of increasing resistivity layers which is interpreted as permeable sandy formation of varying grain sizes, thicknesses and moisture contents.

Hydrogeological features of the study area show that leachate derived from the landfill sites seeps into the vulnerable sand aquifer and hence contaminates the groundwater. This research project has demonstrated that $2 \mathrm{D}$ resistivity imaging can be used to investigate pollutions of top soils and groundwater as well as the lateral extents of the contamination of the leachate plumes from the waste (medical, domestic and industrial) disposal area.

Table 1 shows the interpretation of the processed field data for VES obtained at Olobo environs of Choba/Alakahia and revealed five (5) geoelectric layers of resistivity values ranging from $47.10 \Omega \mathrm{m}-$ $148.30 \Omega \mathrm{m}$ and depth to the layers also ranging from $1.95 \mathrm{~m}-35.28 \mathrm{~m}$. the resistivity of layers of depth and thickness beyond $35.28 \mathrm{~m}$ had poor resolution.

\begin{tabular}{lllll} 
& \multicolumn{4}{c}{ Table 1. Interpretation of processed VES data 2 } \\
\hline No of layers & RES $(\mathbf{R} \boldsymbol{\Omega})$ & Depth $(\mathbf{m})$ & Thickness $(\mathbf{m})$ & Lithological Unit \\
\hline 1. & 47.10 & 1.95 & 1.95 & Top Soil \\
2. & 78.95 & 4.75 & 2.80 & Sand Stone, laterite \\
3. & 166.20 & 13.59 & 8.85 & Clay/Sandy \\
4. & 248.60 & 35.28 & 21.69 & Coarse, Weak Aquifer \\
5. & 148.30 & - & - & Indurate \\
\hline
\end{tabular}

Conclusion: Dumping of waste (domestic, industrial, and medical) in urban or rural settlements without environmental precautions leads to serious health issues. Quality water management is an issue that must be given top priority in our state and country. The hydrogeological features of the vulnerable sandy aquifer are not suitable for waste disposal as contaminants easily seep into the groundwater. Therefore construction of landfill sites must include solutions to landfill problems, such as thick concrete floor, bagging waste in waterproof bags, creating public awareness and immediate recycling.

Acknowledgements: The authors are thankful to Adekunle Sofolabo for his assistance and all others in the Department of Physics who contributed in no small measure to the completion of this work.

\section{REFERENCES}

Abul Salam (2010). Environmental and Health Impact of Solid Waste Disposal at Mangaweni dumpsite in Manzini Swaziland. J. of sustainable Dev. in Africa. 12(7): 1509 - 5520.

Adebibu, EA (1985). Quality Assessment of Groundwater in the vicinity of dumpsites in Lagos, Nigeria. J. of appl. Sci. 2(1): 39-44

Adekunle, A; Kehinde IT (2008). Impact of Industrial effluents on quality of segment of Asa River within and industrial estate in Ilorin Nigeria. $N Y$ sci.j. 1(1): 17-21.

Agbemuko, OS; Tamunobereton-Ari, I; Ngah, SA (2017). Determination of the effects of dumpsites on aquifer at Port Harcourt metropolis, Rivers
State, Nigeria. IOSR-J. of Appl. Phys, 9(6): ver. I, $41-54$.

Ajadike, AT (2007). Waste Management towards Sustainable Development in Nigeria. A Case Study of Lagos State, Nigeria. Int.NGO J. 4(4): 173-179.

Ehirim, CN; Ebeniro, JO; Ogwu, DA (2009a). A geophysical and Hydro-physiochemical impact of a solid Waste Landfill in Port Harcourt municipality, Nigeria. Pac, J. of Sci. and Technol. 10: $596-603$.

Ehirim, CN; Ebeniro, JO; Olanegan, OP (2009b). A geophysical investigation of soild waste landfill, using 2-D Port Harcourt municipality, Rivers state, Nigeria. Pac. J. of Sci. Technol. 10: 604 613.

El Mahmoudi (2010). Application of Resistivity method in environmental study of appearance of soil water in central of Tenth of Ramadan city, Egypt. Quarterly J. of Eng. Geol. and Hydrogeol. 43(2): $171-184$

Esakuku, S; Palamuelu, K; Kuraian J (2003). Assessment of heavy metals in municipal solid wastes dumpsite workshop on sustainable landfill management, Chennai, India, 139-145

Eshimiakhe, D; Jimoh, R; Musa, Z (2019). Twodimensional image of seismic refraction tomography and electrical resistivity tomography survey in a proposed geophysical test site at 
Shika, Ahmadu Bello University Zaria, Nigeria. Global J. of Earth and Environ. Sci. 4(4): 56 - 66.

Ibe, KM; Njoku, JC (1999). Migration of contaminants in groundwater at a landfill site in Owerri, South East, Nigeria. J. of Environ. Hydrol. 7(8): 1 -9

Ige, OO; Ogunsawo, O (2009). Environmental geological assessment of a solid waste disposal site Ilorin southwestern Nigeria. Nat. and sci. 7(9): 53-62.

Inichinbia, S; Sule, PO (2018a). Evaluation of the layering of rock strata and basement rock depth of a university teaching hospital premises in northern Nigeria. J. of Appl. Sci. and Environ. Manage. 22 (4): 597 - 603

Inichinbia, S; Sule, PO (2018b). 2D geo-electrical imaging for groundwater exploration in Shika, along Zaria-Funtua road north of Ahmadu Bello University main campus, Samaru, Zaria. J. of Appl. Sci. and Environ. Manage. 22 (4): 609-612

Loizidou, M; Kapantamos (1993). Effect of leachate from landfill on underground water quality. Sci total environ. 128 (1): 69-81

Olayinka, AI; Olayiwola, MA (2000). Integrated use of Geophysical imaging and hydro-chemical Methods in delineating limit of polluted surface and groundwater at a landfill site in Ibadan Area, S.W Nigeria. J. of Mining and Geol. 37(1): 193 198.
Rosqvist, H; Dahlin, T; Fourie, A; Rohrs, L; Bengtseeon, A; Larsson, M (2003). Mapping of Leachate plumes at two landfill sites in South Africa Geoelectrical Imaging Techniques. Proceedings of $9^{\text {th }}$ Int. Waste Manage. Landfill Symp. Cagliari, Italy. 1 - 10

Sirhan, A; Hamidi, M; Anderieux, P (2011). Electrical Resistivity Tomography, an Assessment Tool for Water Resource: Al-Aroub Basin, West Bank, Palestine Asian J. of Earth Sci. 4(1): 38-45.

Tamuno, W; Inichinbia, S (2019). Vertical Electric Sounding of Leachate Contaminant Plumes at a Dumpsite in Obigbo, Rivers State, Nigeria. $J$. Appl. Sci. Environ. Manage. 23(12): 2245-2249

. Udom, GJ; su, EO (2004). A preliminary Assessment of the Impact of Solid Wastes on Soil and Groundwater System in Parts of Port Harcourt city and its environs, Rivers State, Nigeria. Global J. of Environ. Sci. 4(1): $234-239$

Udom, GJ; EtuEfetor, JO; Esu, EO (1999). Hydrogeochemical of Groundwater in part of Port Harcourt and Tai Eleme Local Government Area, Rivers State. Global J. Pure Appl. Sci. 5: $545-$ 551 